DOI: $10.24193 /$ tras.64E.1

Published First Online: 10/28/2021
THE EFFECTS OF FISCAL

DECENTRALIZATION ON GENERAL

AND LOCAL GOVERNMENT SIZE:

DOES COMPOSITE INDEX MATTER?

\author{
Ebru CANIKALP \\ Taner TURAN \\ ilter ÜNLÜKAPLAN
}

\section{Ebru CANIKALP}

Research Assistant, Department of Public Finance, Cukurova University, Adana, Turkey

Tel.: 0090-3223-387-254-202

E-mail: ecanikalp@cu.edu.tr

\section{Taner TURAN}

Associate Professor, Department of Economics, Cukurova University, Adana, Turkey

Tel.: 0090-322-3387-254-138

E-mail: tturan@cu.edu.tr

\section{İlter ÜNLÜKAPLAN}

Professor, Department of Public Finance, Cukurova University, Adana, Turkey

Tel.: 0090-322-3387-254-215

E-mail: ikaplan@cu.edu.tr do not significantly change when we use different fiscal decentralization indexes. Therefore, we do not find any evidence for the argument that fiscal decentralization would be helpful to restrict the expansion of government size. Moreover, we present some evidence for the flypaper effect. Additionally, we find a positive relationship between fiscal importance and local governments, interpreted as an indicator of expenditure competition instead of race to the bottom.

Keywords: fiscal decentralization, general and local government size, dynamic panel.

* This paper is based on the Ebru Canıkalp's PhD Thesis submitted to Cukurova University, Faculty of Economic and Administrative Sciences, Department of Economics.

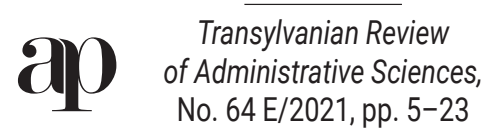




\section{Introduction}

Fiscal decentralization is defined as the devolution of financial power and responsibilities from the central government to local governments (Neyapt1, 2005). There are two main theoretical approaches to fiscal decentralization. First generation theories adopt the benevolent government assumption and explain the concept in a normative way (Oates, 1972; Rubinfeld, 1987). Second generation theories, on the other hand, draw attention to the problems of political institutions and government failure (Weingast, 2008), fiscal incentives (Weingast, 2009; Lockwood, 2015), market preserving fiscal federalism (Weingast, 1995, 2009) and the industrial organization structure (Oates, 2005; Garzarelli, 2004). Despite these differences, both approaches regard fiscal decentralization as a tool to control the government size and protect the private markets from destructive violations (Oates, 2005).

There are two main arguments or motives for fiscal decentralization. First, fiscal decentralization would increase social welfare by ensuring the provision of more efficient public services and accountability due to better preference match and more engagement from voters. Second, fiscal decentralization would lead to a smaller government size. In the famous 'Leviathan' hypothesis developed by Brennan and Buchanan (1980), fiscal decentralization is proposed as a solution to limit the expansion of the public sector. According to this hypothesis, fiscal decentralization tends to constrain governments' Leviathan-type behavior by creating a 'race to bottom' effect. Additionally, Josselin (1995) and Craw (2008) suggest that fiscal decentralization would exert a positive impact on local government size, called Local Leviathan in the literature. This implies that the effects of fiscal decentralization on the size of general and local governments would markedly differ from each other. In other words, fiscal decentralization would be related to a smaller (larger) general (local) government size on theoretical grounds.

Although fiscal decentralization has gained importance and popularity over time, its effects on government size are not clear-cut (Prud'homme, 1995; Tanzi, 2002; Rodden, 2003). Therefore, more empirical studies are deeply needed to shed light on the relationship between fiscal decentralization and government size at both general and local levels. There is no doubt that this issue has very important policy implications for designing and implementing fiscal policy.

Investigating the relationship between fiscal decentralization and government size for 36 countries over the period 1972-2019, this study aims to contribute to the existing literature in three important dimensions. First, we employ alternative indexes to better capture the different sides or aspects of fiscal decentralization. Some early studies including Davoodi and Zou (1998), Ebel and Yllmaz (2002), Stegarescu (2005) employ basic indexes as a proxy for fiscal decentralization due to their simplicity and availability. However, using just basic indexes to measure such a multidimensional concept would be both misleading and unrealistic (OECD, 2013). Therefore, more recent studies, such as Akai and Sakata (2002), Vo (2008), Martínez-Vázquez and Timofeev (2010), develop some composite indexes to avoid the possible problems 
created by basic indexes. To capture the multidimensional aspects of fiscal decentralization, we follow the methodology of Vo (2008) and construct a composite index consisting of two components: fiscal importance and fiscal autonomy. In addition to Vo (2008)'s methodology, we also calculate basic indexes developed by Wallis and Oates (1988) and other composite indexes suggested by Akai and Sakata (2002) and Martínez-Vázquez and Timofeev (2010) to gain additional insights and check for the robustness of the results.

Second, somewhat surprisingly, only a limited number of studies empirically examine the relationship between fiscal decentralization and local government size (Rodden, 2003; Kwon, 2003; Craw, 2008; Boetti, Piacenza and Turati, 2012; Liberati and Sacchi, 2013; Jia, Guo and Zhang, 2014). Therefore, we aim to fill this gap in the literature by investigating the impact of fiscal decentralization on the size of both general and local governments in the same framework. In doing so, we would directly test and compare whether the Leviathan or Local Leviathan is more successful in explaining the effects of fiscal decentralization. Third, due to possible inertia in government spending, we employ a dynamic panel method (Generalized Method of Moments, GMM), which is also well-suited to deal with some econometric problems such as autocorrelation, heteroscedasticity, and endogeneity.

Our empirical results do not lend any evidence for the Leviathan hypothesis. On the other hand, we conclude that there exists a statistically positive relationship between the fiscal decentralization and local government size, supporting the existence of Local Leviathan. We should note that our main results are not sensitive to the choice of fiscal decentralization measure used in the empirical specifications.

The rest of the article is organized as follows. The next section summarizes the empirical literature. In section 3, we present the model specification and the data set. Section 4 reports and discusses the empirical results. The last section contains the conclusions.

\section{Literature review}

As presented in the Annex, although many studies analyze the relationship between fiscal decentralization and general government size with different country groups, time intervals and econometric methods, there is no consensus on the issue whether fiscal decentralization is associated with a smaller government size or not. In other words, there is an ongoing debate as to whether fiscal decentralization would be helpful to limit the expansion of government size, as proposed by Brennan and Buchanan (1980). On the one hand, some studies such as Grossman (1989), Forbes and Zampelli (1989) or Joulfaian and Marlow (1991) found that fiscal decentralization has a negative effect on government size and hence confirm the Leviathan hypothesis. On the other hand, other studies like Oates (1972, 1985), Wallis and Oates (1988), Heil (1991) and Grossman (1992) firmly reject this finding.

In the early studies, consistent with first generation theories, the fiscal decentralization is measured by using basic indexes such as expenditure autonomy (Oates, 
1972, 1985; Wallis and Oates, 1988; Heil, 1991; Grossman 1989, 1992; Joulfaian and Marlow, 1991), revenue autonomy (Wallis and Oates, 1988; Heil, 1991; Grossman, 1992) or province number (Forbes and Zampelli, 1989; Joulfaian and Marlow, 1991). However, since the first-generation theories neglect or ignore some important points such as lack of local own source revenue, soft budget constraints, fiscal inequalities and bailout effects, second generation theories have emerged and paid attention to these issues (Dziobek, Mangas and Kufa, 2011). These new theories show that measuring fiscal decentralization with revenue or expenditure autonomy instead of a more comprehensive index would cause a significant information loss in empirical studies (Martínez-Vázquez, Lago-Penas and Sacchi, 2017).

Therefore, later studies suggest more specific or comprehensive proxies for fiscal decentralization by considering additional dimensions such as own revenues (Rodden, 2003), vertical fiscal inequalities (Stein, 1999; Jia, Guo and Zhang, 2014; MakreshanskaMladenovska and Petrevski, 2019), tax autonomy (Ehdaie, 1994; Kwon, 2013; Qiao, Ding and Liu, 2019) and composite indexes (Ehdaie, 1994; Prohl and Schneider, 2009; Qiao, Ding and Liu, 2019). Based on these more comprehensive or composite indexes, some studies such as Ehdaie (1994), Moesen and van Cauwenberge (2000), Rodden (2003), Prohl and Schneider (2009), Herwartz and Theilen (2017), Makreshanska-Mladenovska and Petrevski (2019), and Qiao, Ding and Liu (2019) support the Leviathan hypothesis, while other studies including Stein (1999), Martínez-Vázquez and Yao (2009), Cassette and Paty (2010), Baskaran (2011), Kwon (2013), Jia, Guo and Zhang (2014) reject this hypothesis. In other words, some studies empirically support the argument that fiscal decentralization would lead to a reduction in the government size while others do not. This implies that using more composite indexes dos not necessarily resolve the disagreement. The rejection of the Leviathan hypothesis might be associated with transfer dependency (Stein, 1999), common pool problem (Baskaran, 2011; Jia, Guo and Zhang, 2014) and corruption (Martínez-Vázquez and Yao, 2009).

Failure to find a strong or decisive negative relationship between fiscal decentralization and government size in the empirical studies supports the emergence of Local Leviathan in the literature (Josselin, 1995; Craw, 2008). We should note that, despite a rich literature on the relationship between fiscal decentralization and general government size, there are relatively few empirical studies examining the impact of decentralization on local government size (Jin and Zou, 2002; Cassette and Paty, 2010; Liberati and Sacchi, 2013; Jia, Guo and Zhang, 2014; Sacchi and Salotti, 2017). Using tax or revenue autonomy for fiscal decentralization some studies like Liberati and Sacchi (2013), Boetti, Piacenza and Turati (2012) found a negative impact on the local government size, while other studies including Jin and Zou (2002), Jia, Guo and Zhang (2014) did not. On the other hand, using the expenditure autonomy, Jin and Zou (2002), Kwon (2003), Jia, Guo and Zhang (2014) and Zhang (2016) report a positive relationship between fiscal decentralization and the local government size. Apart from these studies, Boetti, Piacenza and Turati (2012) confirm the Local Leviathan 
hypothesis by using the Akai and Sakata (2002) composite index. Moreover, using fiscal inequalities or transfers as a measure for fiscal decentralization some empirical studies (among them Jin and Zou, 2002; Borge and Rattso, 2002; Liberati and Sacchi, 2013; Jia, Guo and Zhang, 2014; Sacchi and Salotti, 2017; Cassette and Paty, 2010; Jia, Martínez-Vázquez and Zhang, 2021) found a positive effect on the size of the local government. This positive relationship is supported by transfer dependency (Liberati and Sacchi, 2013), common pool problem (Borge and Rattso, 2002; Jia, Guo and Zhang 2014; Sacchi and Salotti, 2017) and tax effort (Jia, Martínez-Vázquez and Zhang, 2021).

We conclude that despite a considerable empirical attention to the effects of fiscal decentralization on the general and local government size, there is yet no consensus. However, this is hardly surprising. Different fiscal decentralization indexes, sample countries and periods, and even econometric methods would naturally lead to different or even conflicting results. Nonetheless, we should highlight two important points. First, making a distinction among different fiscal decentralization measures would matter. Second, there exists a clear difference between general and local governments regarding the effects of fiscal decentralization, consistent with theoretical explanations. Common fiscal decentralization indexes such as revenue or expenditure indexes (basic indexes) tend to over-estimate (Stegarescu, 2005; Casettte and Paty, 2010).

\section{Data and model specification}

Following some studies such as Liberati and Sacchi (2013) and MakreshanskaMladenovska and Petrevski (2019), we test the validity of two hypotheses, namely the Leviathan hypothesis (general government - GG) and the Local Leviathan hypothesis (local government - LG). We can write our baseline empirical specification as follows:

$$
G_{i t}=\beta_{0}+\beta_{1} G_{i t-1}+\beta_{2} F_{i t}+\beta_{3} X_{i t}++\epsilon_{i t}
$$

where is the dependent variable, which is government size for $i$ country at the end of year $t$ (GG or $L G), G_{i t-1}$ is the lagged value of dependent variable, FD stands for fiscal decentralization index, $X$ is a vector of control variables, $\beta_{3}$ is a vector of explanatory variables and $\epsilon_{\mathrm{it}}$ is error term. Lagged explanatory variables are widely used in public economics in response to endogeneity concerns (Bellemare, Masaki and Pepinsky, 2017). At the theoretical level, public budgets are generally not created each year independently from other years' budgets, even in the process of budget preparation, they are related to budgets of the previous years. For this reason, we include the lagged dependent variable in the model.

We calculate a composite index of fiscal decentralization developed by Vo (2008) that considers the expenditure decisions, taxing powers, fiscal transfers and subnational borrowings. Besides, it is possible to calculate this index using the IMF's GFS data. This composite index is based on two important indicators: fiscal importance 
and fiscal autonomy. Fiscal autonomy (FA) is expressed as the ratio of local governments' own revenues (OSR) to local governments' expenditures (E).

$$
F A=\frac{\sum_{i=1}^{P} O S R i}{\sum_{i=1}^{p} E i}
$$

$\mathrm{OSR}_{\mathrm{i}}$ and $\mathrm{E}_{\mathrm{i}}$ represent the local government's own revenues and expenditures of i regions. The fiscal importance index can be expressed as an indicator of the efficiency:

$$
F I=\frac{\sum_{i=1}^{P} E i}{T E}
$$

TE refers to the government's total public sector expenditure (i.e., the sum of central and local government expenditures), excluding fiscal transfers from one government level to another. We calculate FD as the geometric mean of fiscal autonomy and fiscal importance indicators:

$$
F D=(F A \times F I)^{1 / 2} \sqrt{\left(\frac{\sum_{i=1}^{P} O S R i}{\sum_{i=1}^{p} E i}\right) \times\left(\frac{\sum_{i=1}^{P} E i}{T E}\right)}
$$

To gain additional insights and check the sensitivity of the results, we also use basic and other composite indexes frequently employed in empirical studies. We employ two basic indexes of fiscal decentralization. In this context, we define the expenditure autonomy (BAS1) as the ratio of local government expenditures to total public expenditures (Wallis and Oates, 1988; Davoodi and Zou, 1998). Similarly, we define revenue autonomy (BAS2) as the ratio of local governments' own revenues to their total revenues (Stegarescu, 2005; Eyraud and Lusinyan, 2011).

In addition to these basic indexes, we employ two composite indexes developed by Akai and Sakata (2002) and Martínez-Vázquez and Timofeev (2010) to supplement our estimations. Akai and Sakata (2002, pp. 96-98) measure fiscal decentralization with the production-revenue indicator (COM1). The revenue (production) indicator refers to the share of local government revenues (expenditures) in total budget revenue (expenditure); the index combines a geometric average of the two indicators. Secondly, Martínez-Vázquez and Timofeev (2010) suggest a composite index based on expenditure autonomy and revenue autonomy; this index (COM2) is defined as the ratio of revenue autonomy to expenditure centralization (i.e., 1 - Expenditure ratio).

Following the literature, we include many control variables: per capita GDP growth (GDP), general public debt (DEBT), inflation (INF), urban population to total population (URBAN), trade openness (TRADE), population aged 65 and over to the total population (ELDER), local democracy (LD) and annual population growth rate (POP). It is expected that GDP (Rodden, 2003; Wu and Lin, 2012), INF (Olivera, 1969) and LD (Asatryan, 2016; Matsusaka, 2017) will have a positive effect on LG and GG. On the other hand, we expect that other control variables will have different signs or effects on LG and GG. It is assumed that ELDER (Arvate, 2011), POP (Sow and Razafimahefa, 
2015) and TRADE (Rodrik, 1998) have a positive effect on general government, but an insignificant effect on local government. Lastly, we assume that DEBT and URBAN have an uncertain effect on GG and LG (Bordignon, 2004; Makreshanska-Mladenovska and Petrevski, 2019). We employ unbalanced panel data with 5-year non-overlapping averages for the period 1972-2019 for a sample of 36 countries. The data availability dictates our sample countries and periods for which we can calculate the aforementioned fiscal decentralization indexes. The variables, definitions and data sources are summarized in Table 1.

Table 1: Variables, definitions and data source

\begin{tabular}{|c|c|c|}
\hline Variable & Definitions & Source \\
\hline \multicolumn{3}{|c|}{ Leviathan and Local Leviathan Hypothesis Dependent Variables } \\
\hline LG & Local Government Expenditures / GDP & IMF Database \\
\hline GG & General Government Expenditures / GDP & IMF Database \\
\hline \multicolumn{3}{|c|}{ Independent Variable } \\
\hline FD & Fiscal Decentralization Index & Calculated by authors \\
\hline \multicolumn{3}{|c|}{ Control Variable } \\
\hline GDP & GDP per capita growth (\% annual) & World Bank Database \\
\hline INF & Consumer prices (\% annual) & World Bank Database \\
\hline DEBT & General public debt (\% GDP) & World Bank Database \\
\hline POP & Population growth rate (\% annual) & World Bank Database \\
\hline ELDER & $65+$ Population / Total Population & World Bank Database \\
\hline URBAN & Urban Population / Total Population & World Bank Database \\
\hline TRADE & Trade openness (\% of GDP) & World Bank Database \\
\hline LD & Local Democracy Index & World Bank Database \\
\hline
\end{tabular}

* Used for robustness testing; BAS1, BAS2 represent basic indexes, and COM1, COM2 stands for the composite indexes.

**TR and TAX represent transfer dependency and tax autonomy, respectively. These variables are calculated by authors for all countries, taking into account the calculations of Eyraud and Lusinyan (2013) and Fiva (2006), respectively. TR is measured as the ratio of net transfer to subnational own spending while TAX is measured as the ratio of local tax revenue to general tax revenue.

Source: Authors' research results

Since we include the lagged value of the dependent variable in our empirical specification, we employ the General Method of Moments (GMM), developed by Arellano and Bond (1991), Arellano and Bover (1995), and Blundell and Bond (1998); GMM method has some well-known advantages to deal with some common and important econometric problems such as endogeneity, autocorrelation, and heteroscedasticity (Roodman, 2009). To avoid the instrument proliferation problem, the number of instruments should be equal to or less than the number of groups (Roodman, 2009). We employ Hansen's J test to validate of instruments as suggested by Baum, Schaffer and Stillman (2007). We also use AR tests to test for autocorrelation as suggested by Arellano and Bond (1991). 


\section{Empirical results}

We report our baseline regression results in Table 2. Before interpreting our results, we should note that no autocorrelation and overidentification problems exist in our estimates. There is a positive but insignificant relationship between FD and GG. This suggests that fiscal decentralization does not lead to a reduction in the government size, implying the rejection of the Leviathan hypothesis. Note that our result is consistent with that of many previous studies (Oates, 1985; Heil, 1991; Grossman, 1992). On the other hand, there is a statistically significant and positive relationship at the $1 \%$ level between FD and LG, lending strong evidence for the existence of Local Leviathan (Jin and Zou, 2002; Kwon, 2003; Kwon, 2013; Sacchi and Salotti, 2017). In other words, our results support the argument that fiscal decentralization leads to an increase in local government size. Indeed, local governments would prefer expansionary policies as 'expenditure competition' (Rodden, 2003; Jia, Guo and Zhang, 2014; Zhang, 2016) instead of a 'race to bottom' approach. We think that this result is plausible. If a central government transfers the provision of some public goods or responsibilities to the local governments then it is possible to observe an expansion in the local government size.

Table 2: Baseline regression:

Effect of fiscal decentralization (FD) on public sector size at local (LG) and general levels (GG)

\begin{tabular}{lll}
\hline & \multicolumn{1}{c}{ GG } & \multicolumn{1}{c}{ LG } \\
\hline L.GG / L.LG & $0.24^{\star \star \star}$ & $0.211^{\star \star \star}$ \\
FD & 1.38 & $7.89^{\star \star}$ \\
GDP & $-0.839^{\star \star \star}$ & $-0.191^{\star \star}$ \\
\hline DEBT & $-1.9 \mathrm{e}-12$ & $5.2 \mathrm{e}-13$ \\
INF & $0.123^{\star \star}$ & 0.0156 \\
\hline TRADE & 0.0259 & 0.00893 \\
\hline POP & $0.0468^{\star}$ & 0.0133 \\
\hline URBAN & 0.0271 & $0.125^{\star}$ \\
\hline LD & 5.19 & $11.2^{\star \star \star}$ \\
\hline ELDER & $0.688^{\star}$ & 0.476 \\
\hline Diagnostic Tests & & \\
\hline Obs. & 201 & 207 \\
\hline Group-Instrument & $34-34$ & $34-34$ \\
\hline AR1 & 0.129 & 0.592 \\
\hline AR2 & 0.164 & 0.316 \\
\hline Hansen & 17.4 & 12.6 \\
\hline
\end{tabular}

The model includes time dummies but not constant terms. $t$ statistics are represented by $* * *, * *$ and state the significance at the level of $1 \%, 5$ and $10 \%$, respectively.

Source: Authors' research results 
We should add that the lagged dependent variable has a statistically significant effect, supporting the dynamic specification. It seems that GDP exerts a negative impact on the general and local government. Therefore, our results suggest that income elasticity of government provided goods and services is not greater than 1. Apart from these findings, INF, POP and ELDER have a positive effect on GG, whereas LD and URBAN exert a positive effect on LG. Our results are in line with previous studies such as Olivera (1969), Arvate (2011) and Asatryan (2016).

Since general governments mainly meet the public goods and service demands of the elderly population (social expenditures, social security services, pension payments and health services) a positive coefficient on ELDER for GG is consistent with our priori expectations (Arvate, 2011). Another important finding is that LD and URBAN exert a positive impact on LG. Voters at the local level would put more electoral pressure on politicians, leading to an increase in the public expenditures. Moreover, it seems that democracy does not function as a restriction against the Leviathan government. Our findings are in line with that of some previous studies (Asatryan, 2016).

To supplement our baseline regressions, we estimate alternative specifications with different fiscal decentralization indexes (BAS1, BAS2, COM1 and COM2) in Table 3. Similar to our previous results, there does not exist a significant relationship between fiscal decentralization indexes and GG, indicating the absence of Leviathan. On the other hand, all alternative fiscal decentralization indexes (BAS 1, BAS2, COM1 and COM2) have a significantly positive impact on the local government size. Therefore, we conclude that our results robustly and consistently support the Local Leviathan hypothesis. Importantly, this clearly indicates that our baseline results are not sensitive to the choice of fiscal decentralization indexes used in the empirical analysis.

Furthermore, to gain additional insight we estimate our specifications with two extensions. In the first, we use the fiscal autonomy (FA) and fiscal importance (FI) sub-indexes instead of the fiscal decentralization index of Vo (2008). In the second extension, we add the transfer dependency (TR) and tax autonomy (TAX) to the model. Table 4 reports the results of these extended specifications. It seems that there is a significant and positive impact of FA on GG while FI has a positive effect on LG. We think that at least two reasons would explain the relationship between the FA and GG (Oulasvirta and Turala, 2009). First, local governments would have fiscal autonomy but not spending autonomy. In other words, local governments could not have the right or power to determine or change the expenditure policy because of legislation. As a result, public goods are provided by the general government. Second, a strong fiscal autonomy creates some socio-economic problems due to the absence of good governance and democracy. Conversely, FI creates a pressure to spend more at local level (Rodden, 2003; Jia, Guo and Zhang, 2014; Zhang, 2016). This could lead to an increase in the local government size. 


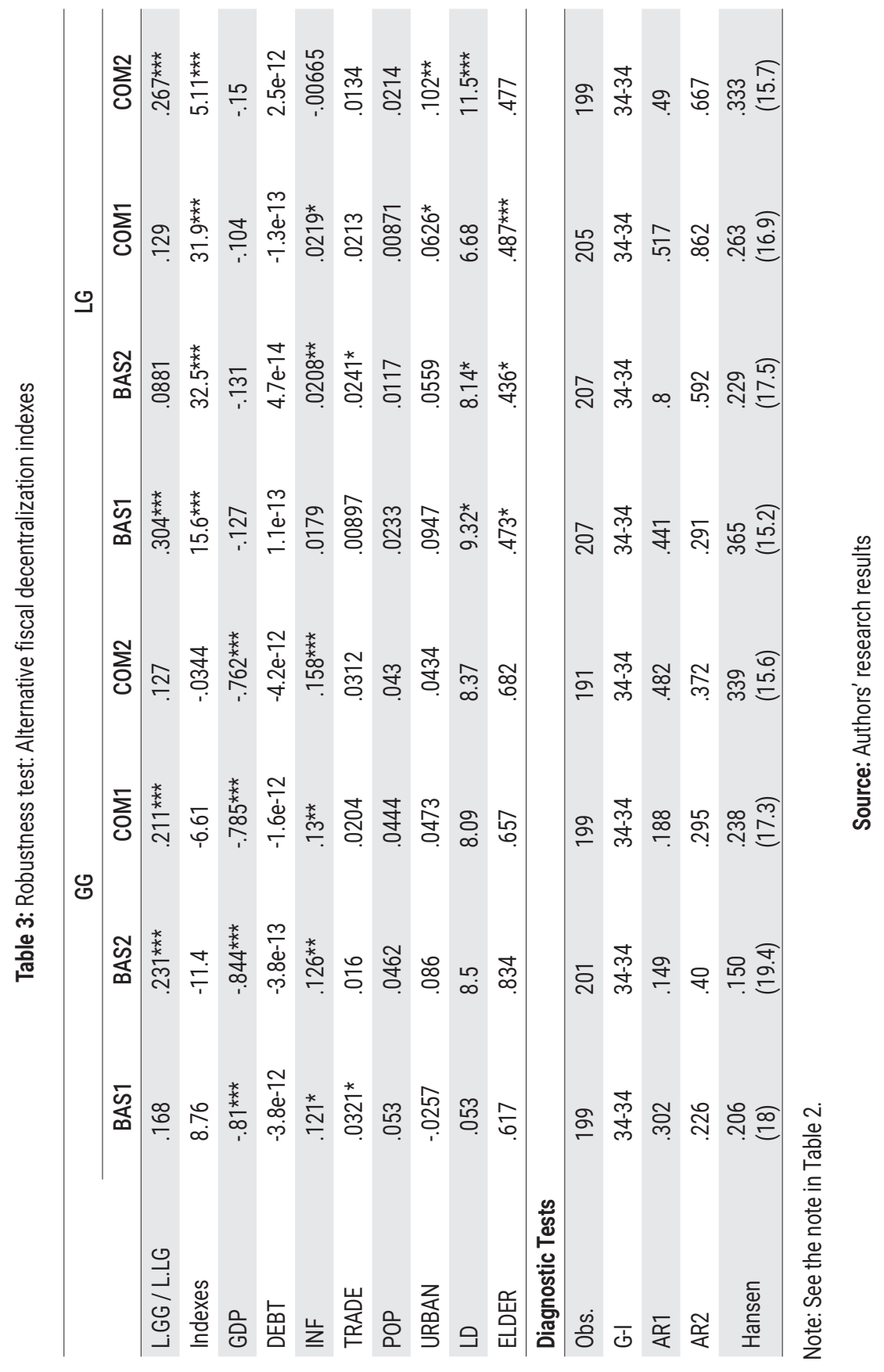


Table 4: Extended specification: Sub-fiscal decentralization indexes

\begin{tabular}{|c|c|c|c|c|}
\hline & GG & GG & LG & LG \\
\hline L.GG / L.LG & 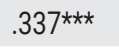 & $.305^{\star \star \star}$ & $.240 \star \star$ & $.287^{\star}$ \\
\hline FD & & 5.74 & & $20.6 * \star$ \\
\hline TR & & $-2.35^{\star}$ & & $2.8 * \star$ \\
\hline TAX & & -18.9 & & 2.39 \\
\hline FA & $6.05 *$ & & 1.09 & \\
\hline $\mathrm{Fl}$ & -1.23 & & $17.2^{\star \star \star}$ & \\
\hline GDP & $-.789 * \star \star$ & $-.815^{\star \star \star}$ & $-.131^{*}$ & $-.196^{*}$ \\
\hline DEBT & $-2.2 e-12$ & $-2.8 \mathrm{e}-12$ & $3.2 \mathrm{e}-13$ & $1.8 \mathrm{e}-12$ \\
\hline INF & $.134^{*}$ & $.116 * \star$ & .0218 & $.025^{\star}$ \\
\hline TRADE & .00953 & .00983 & $.0181^{*}$ & .03 \\
\hline POP & .0487 & $.0952^{\star \star}$ & 0.14 & -.0443 \\
\hline URBAN & .0169 & .0757 & $.0586^{\star}$ & .0517 \\
\hline LD & 4.85 & $13.5^{\star \star}$ & $9.77^{\star \star}$ & 4.54 \\
\hline ELDER & .622 & .851 *** & $.498 *$ & $.59 * *$ \\
\hline \multicolumn{5}{|l|}{ Diagnostic Tests } \\
\hline Obs. & 201 & 200 & 207 & 206 \\
\hline Group-Instrument & $34-38$ & $31-34$ & $34-38$ & $31-34$ \\
\hline AR1 & 0.0594 & 0.149 & 0.9 & 0.86 \\
\hline AR2 & 0.141 & 0.294 & 0.798 & 0.299 \\
\hline Hansen & $\begin{array}{l}0.443 \\
(17.2)\end{array}$ & $\begin{array}{l}0.331 \\
(15.7)\end{array}$ & $\begin{array}{l}0.489 \\
(16.5)\end{array}$ & $\begin{array}{l}0.19 \\
(18.4)\end{array}$ \\
\hline
\end{tabular}

Note: See the note in Table 2.

Source: Authors' research results

On the other hand, when we include the transfer dependency and tax autonomy as additional controls to the model, we do not find a statistically significant relationship between the FD and GG. This result confirms the absence of the Leviathan once again. In addition, there is a statistically significant and negative relationship between TR and GG. This particular result shows that although central governments would offer some fiscal transfers and incentives to the local governments, they might lower their own expenditure (Bordignon, 2004). From this point of view, transfer dependency can create a contractionary effect at the general government level, but this effect is not associated with hard budget constraints. Local governments would tend to overspend due to revenues from fiscal transfers, incentives and common pool (Stein, 1999; Cassette and Patty, 2010; Sacchi and Salotti 2017) instead of their own revenues. These effects create an expansionary expenditure policy at local level.

In the second extended specification, we find a positive and significant relationship between FD and LG, confirming the validity of the Local Leviathan hypothesis. Furthermore, there is a statistically significant and positive relationship between TR 
and LG. This indicates that transfer dependency would affect the size of local government based on expenditure competition and flypaper effect. Local governments use transfers from the central government to expand their budgets (Gramlich et al., 1973). This implies that transfers received by local governments tend to 'stick where it hits' (Hines and Thaler, 1995).

\section{Conclusion}

Using Vo's (2008) fiscal decentralization index for 36 countries and system GMM, we examine both Local Leviathan and Leviathan hypothesis. Our results firmly reject the validity of the Leviathan hypothesis, consistent with previous studies such as Oates (1985), Heil (1991), Grossman (1992). On the other hand, we find robust evidence for the presence of the Local Leviathan hypothesis as suggested by Rodden (2003), Kwon (2003) and Kwon (2013). In other words, it seems that fiscal decentralization is not associated with a reduction in general government size while it leads to an increase in local government size. Contrary to what is stated in theory, there is an 'expenditure competition' (Rodden, 2003), as opposed to a 'race to the bottom' (Brennan and Buchanan, 1980; Weingast 1995). We find similar results when we employ alternative measures for fiscal decentralization.

Moreover, we extend our baseline specification to check the robustness of our results. It seems that an increase in transfer dependency creates a flypaper effect in local governments while a negative effect is detected at general government level. This indicates that even though central governments follow a low expenditure policy (Bordignon, 2004), local governments could easily spend fiscal transfers and incentives received from the central government than local own-source revenue (Stein, 1999; Cassette and Patty, 2010; Sacchi and Salotti 2017). Furthermore, the relationship between the tax autonomy and LG is positive and significant, while a negative effect exists on GG. In the other specifications, there is a statistically significant and positive relationship between FI and LG, whereas a significant and positive relationship exists between FA and GG.

Finally, this study clearly demonstrates that fiscal decentralization is not a solution to control the expansion of the general government size. Rather, it seems that fiscal decentralization is consistently associated with an increase in local government size. This positive relationship between the local government size and fiscal decentralization suggests that the existence of a race to bottom effect is rejected. On the other hand, our study does not focus on whether fiscal decentralization would be associated with an increase in the economic efficiency or better provision of public goods. This would be an interesting research question for future studies. In this context, it is possible to test the relationship between fiscal decentralization and government efficiency. More specifically, do countries with a higher fiscal decentralization have more efficient governments as well? Similarly, it would be a worthwhile effort to determine whether increased local expenditure is related to welfare policies proposed 
in fiscal decentralization theory. We think that it would be interesting to examine the effects of fiscal decentralization on the composition of general and local government expenditures in the same framework.

\section{Reference:}

1. Akai, N. and Sakata, M., 'Fiscal Decentralization Contributes to Economic Growth: Evidence from State-level Cross-section Data for the United States', 2002, fournal of Urban Economics, vol. 52, no. 1, pp. 93-108.

2. Arellano, M. and Bond, S., 'Some Tests of Specification for Panel Data: Monte Carlo Evidence and an Application to Employment Equations', 1991, The Review of Economic Studies, vol. 58, no. 2, pp. 277-297.

3. Arellano, M. and Bover, O., 'Another Look at The Instrumental Variable Estimation of Error-Components Models', 1995, fournal of Econometrics, vol. 68, no. 1, pp. 29-51.

4. Arvate, P.R., 'The Elderly Population and the Size and Composition of Local Government in Brazil', 2011, [Online] available at https://papers.ssrn.com/sol3/papers.cfm?abstract_ id=1824518, accessed on March 1, 2021.

5. Asatryan, Z., 'The Indirect Effects of Direct Democracy: Local Government Size and Non-Budgetary Voter Initiatives in Germany', 2016, International Tax and Public Finance, vol. 23, no. 3, pp. 580-601.

6. Baskaran, T., 'Fiscal Decentralization, Ideology, and the Size of The Public Sector', 2011, European fournal of Political Economy, vol. 27, no. 3, pp. 485-506.

7. Baum, C.F., Schaffer, M.E. and Stillman, S., 'Enhanced Routines for Instrumental Variables/ Generalized Method of Moments Estimation and Testing', 2007, The Stata Journal, vol. 7, no. 4, pp. 465-506.

8. Bellemare, M.F., Masaki, T. and Pepinsky, T.B., 'Lagged Explanatory Variables and the Estimation of Causal Effect', 2017, The fournal of Politics, vol. 79, no. 3, pp. 949-963.

9. Blundell, R. and Bond, S., 'Initial Conditions and Moment Restrictions in Dynamic Panel Data Models', 1998, Journal of Econometrics, vol. 87, no. 1, pp. 115-143.

10. Boetti, L., Piacenza, M. and Turati, G., 'Decentralization and Local Governments' Performance: How Does Fiscal Autonomy Affect Spending Efficiency?’, 2012, FinanzArchiv/Public Finance Analysis, vol. 68, no. 3, pp. 269-302.

11. Bordignon, M., 'Fiscal Decentralization: How to Achieve a Hard Budget Constraint', 2004, Fiscal Surveillance in EMU: New Issues and Challenges Workshop, Brussels, [Online] available at https://ec.europa.eu/economy_finance/events/2004/bxl1104/papers/bordignon_en.pdf, accessed on March 1, 2021.

12. Borge, L.E. and Rattsø, J., 'Spending Growth with Vertical Fiscal Imbalance: Decentralized Government Spending in Norway, 1880-1990’, 2002, Economics \& Politics, vol. 14, no. 3, pp. 351-373.

13. Brennan, G. and Buchanan, J.M., The Power to Tax: Analytical Foundations of a Fiscal Constitution, Cambridge: Cambridge University Press, 1980.

14. Cassette, A. and Paty, S., 'Fiscal Decentralization and the Size of Government: A European Country Empirical Analysis', 2010, Public Choice, vol. 143, no. 1-2, pp. 173-189. 
15. Craw, M., 'Taming the Local Leviathan: Institutional and Economic Constraints on Municipal Budgets', 2008, Urban Affairs Review, vol. 43, no. 5, pp. 663-690.

16. Davoodi, H. and Zou, H.F., 'Fiscal Decentralization and Economic Growth: A Cross-country Study', 1998, Journal of Urban Economics, vol. 43, no. 2, pp. 244-257.

17. Dziobek, C.H., Mangas, C.A.G. and Kufa, P., 'Measuring Fiscal Decentralization: Exploring the IMF's Databases', 2011, IMF Working Papers, no. 126.

18. Ebel, R.D. and Yilmaz, S., 'On the Measurement and Impact of Fiscal Decentralization', 2002, Policy Research Working Paper Series, WPS 2809, The World Bank Group.

19. Ehdaie, J., 'Fiscal Decentralization and the Size of the Government: An Extension with Evidence from Cross-Country Data', 1994, Policy Research Working Paper Series, WPS 1387, The World Bank Group.

20. Eyraud, L. and Lusinyan, L., 'Decentralizing Spending More Than Revenue: Does it Hurt Fiscal Performance?', 2011, IMF Working Papers, no. 11/226.

21. Eyraud, L. and Lusinyan, L., 'Vertical Fiscal Imbalances and Fiscal Performance in Advanced Economies', 2013, Journal of Monetary Economics, vol. 60, no. 5, pp. 571-587.

22. Fiva, J.H., 'New Evidence on the Effect of Fiscal Decentralization on the Size and Composition of Government Spending', 2006, FinanzArchiv / Public Finance Analysis, vol. 62, no. 2, pp. 250-280.

23. Forbes, K.F. and Zampelli, E.M., 'Is Leviathan a Mythical Beast?', 1989, The American Economic Review, vol. 79, no. 3, pp. 568-577.

24. Garzarelli, G., 'Old and New Theories of Fiscal Federalism, Organizational Design Problems, and Tiebout', 2004, Journal of Public Finance and Public Choice, vol. 22, no. 1-2, pp. 91-104.

25. Gramlich, E.M., Galper, H., Goldfeld, S. and McGuire, M., 'State and Local Fiscal Behavior and Federal Grant Policy', 1973, Brookings Papers on Economic Activity, vol. 1973, no. 1, pp. 15-65.

26. Grossman, P.J., 'Fiscal Decentralization and Government Size: An Extension', 1989, Public Choice, vol. 62, no. 1, pp. 63-69.

27. Grossman, P.J., 'Fiscal Decentralization and Public Sector Size in Australia', 1992, Economic Record, vol. 68, no. 3, pp. 240-246.

28. Heil, J.B., 'The Search for Leviathan Revisited', 1991, Public Finance Quarterly, vol. 19, no. 3, pp. 334-346.

29. Herwartz, H. and Theilen, B., 'Fiscal Decentralization and Public Spending: Evidence from Heteroscedasticity-based Identification', 2017, The BE fournal of Economic Analysis \& Policy, vol. 17, no. 2, pp. 1-8.

30. Hines, J.R. and Thaler, R.H., 'The Flypaper Effect', 1995, Journal of Economic Perspectives, vol. 9, no. 4, pp. 217-226.

31. IMF, 'Government Finance Statistic', [Online] available at https://data.imf.org/?sk=a08 67067-d23c-4ebc-ad23-d3b015045405, accessed on December 1, 2020.

32. Jia, J., Guo, Q. and Zhang, J., 'Fiscal Decentralization and Local Expenditure Policy in China', 2014, China Economic Review, vol. 28, pp. 107-122.

33. Jia, J., Liu, Y., Martínez-Vázquez, J. and Zhang, K., 'Vertical Fiscal Imbalance and Local Fiscal Indiscipline: Empirical Evidence from China', 2021, European fournal of Political Economy, vol. 68, art. no. 101992. 
34. Jin, J. and Zou, H.F., 'How Does Fiscal Decentralization Affect Aggregate, National, and Subnational Government Size?', 2002, Journal of Urban Economics, vol. 52, no. 2, pp. 270-293.

35. Josselin, J.M., 'Towards a Tax Constitution for Local Leviathans. A Tentative Proposal', 1995, Journal des Économistes et des Études Humaines, vol. 6, no. 2-3, pp. 321-334.

36. Joulfaian, D. and Marlow, M.L., 'Centralization and Government Competition', 1991, Applied Economics, vol. 23, no. 10, pp. 1603-1612.

37. Kwon, O., 'Fiscal Decentralization: An Effective Tool for Government Reform?', 2013, Public Administration, vol. 91, no. 3, pp. 544-560.

38. Kwon, O., 'The Effects of Fiscal Decentralization on Public Spending: The Korean Case', 2003, Public Budgeting \& Finance, vol. 23, no. 4, pp. 1-20.

39. Liberati, P. and Sacchi, A., 'Tax Decentralization and Local Government Size', 2013, Public Choice, vol. 157, no. 1-2, pp. 183-205.

40. Lockwood, B., 'The Political Economy of Decentralization', in Ahmad, E. (ed.), Handbook of Multilevel Finance, Edward Elgar Publishing, 2015, pp. 35-69.

41. Makreshanska-Mladenovska, S. and Petrevski, G., 'Fiscal Decentralization and Government Size: Evidence from a Panel of European Countries', 2019, Hacienda Publica Espanola / Review of Public Economics, vol. 229, no. 2, pp. 33-58.

42. Martínez-Vázquez, J. and Timofeev, A., 'Decentralization Measures Revisited', 2010, Public Finance and Management, vol. 10, no. 1, pp. 13-47.

43. Martínez-Vázquez, J. and Yao, M.H., 'Fiscal Decentralization and Public Sector Employment: A Cross-country Analysis', 2009, Public Finance Review, vol. 37, no. 5, pp. 539-571.

44. Martínez-Vázquez, J., Lago-Peñas, S. and Sacchi, A., 'The Impact of Fiscal Decentralization: A Survey', 2017, Journal of Economic Surveys, vol. 31, no. 4, pp. 1095-1129.

45. Matsusaka, J.G., 'Public Policy and the Initiative and Referendum: A Survey with Some New Evidence', 2017, Public Choice, vol. 174, no. 1, pp. 107-143.

46. Moesen, W. and Van Cauwenberge, P., 'The Status of the Budget Constraint, Federalism and the Relative Size of Government: A Bureaucracy Approach', 2000, Public Choice, vol. 104, no. 3, pp. 207-224.

47. Neyapti, B., 'Equalization via Fiscal Decentralization', 2005, Discussion Paper no. 2005/11, Turkish Economic Association, Ankara, [Online] available at https://www.econstor.eu/ handle/10419/83253, accessed on March 2, 2021.

48. Oates, W.E., 'Searching for Leviathan: An Empirical Study', 1985, The American Economic Review, vol. 75, no. 4, pp. 748-757.

49. Oates, W.E., 'Toward a Second-Generation Theory of Fiscal Federalism', 2005, International Tax and Public Finance, vol. 12, no. 4, pp. 349-373.

50. Oates, W.E., Fiscal Federalism, New York: Harcourt Brace Jovanovich, 1972.

51. OECD/Korea Institute of Public Finance, 'Measuring Fiscal Decentralization: Concepts and Policies, OECD Fiscal Federalism Studies', 2013, OECD Publishing, [Online] available at http://dx.doi.org/10.1787/9789264174849-en, accessed on June 14, 2021.

52. Olivera, J.H., 'A Note on the Optimal Rate of Growth of International Reserves', 1969, fournal of Political Economy, vol. 77, no. 2, pp. 245-248.

53. Oulasvirta, L. and Turala, M., 'Financial Autonomy and Consistency of Central Government Policy towards Local Governments', 2009, International Review of Administrative Sciences, vol. 75, no. 2, pp. 311-332. 
54. Prohl, S. and Schneider, F., 'Does Decentralization Reduce Government Size? A Quantitative Study of the Decentralization Hypothesis', 2009, Public Finance Review, vol. 37, no. 6, pp. 639-664.

55. Prud'homme, R., 'The Dangers of Decentralization', 1995, The World Bank Research Observer, vol. 10, no. 2, pp. 201-220.

56. Qiao, M., Ding, S. and Liu, Y., 'Fiscal Decentralization and Government Size: The Role of Democracy', 2019, European fournal of Political Economy, vol. 59, pp. 316-330.

57. Rodden, J., 'Reviving Leviathan: Fiscal Federalism and the Growth of Government', 2003, International Organization, vol. 57, no. 4, pp. 695-729.

58. Rodrik, D., 'Why Do More Open Economies Have Bigger Governments?', 1998, fournal of Political Economy, vol. 106, no. 5, pp. 997-1032.

59. Roodman, D., 'How to Do Xtabond2: An Introduction to Difference and System GMM in Stata', 2009, The Stata fournal, vol. 9, no. 1, pp. 86-136.

60. Rubinfeld, D.L., 'The Economics of the Local Public Sector', in Feldstein, M. and Auerbach, A.J. (eds.), Handbook of Public Economics, vol. II, Amsterdam: Elsevier, 1987, pp. 571-645.

61. Sacchi, A. and Salotti, S., 'The Influence of Decentralized Taxes and Intergovernmental Grants on Local Spending Volatility', 2017, Regional Studies, vol. 51, no. 4, pp. 507-522.

62. Sow, M. and Razafimahefa, M.I.F., Fiscal Decentralization and the Efficiency of Public Service Delivery, International Monetary Fund, WP 15/59, 2015.

63. Stegarescu, D., 'Public Sector Decentralization: Measurement Concepts and Recent International Trends', 2005, Fiscal Studies, vol. 26, no. 3, pp. 301-333.

64. Stein, E., 'Fiscal Decentralization and Government Size in Latin America', 1999, fournal of Applied Economics, vol. 2, no. 2, pp. 357-391.

65. Tanzi, V., 'Pitfalls on The Road to Fiscal Decentralization', in Ahmad, E. and Tanzi, V. (eds.), Managing Fiscal Decentralization, London: Routledge, 2002, pp. 17-30.

66. Vo, D.H., 'Parte Prima-Fiscal Decentralization Indices: A Comparison of Two Approaches', 2008, Rivista di Diritto Finanziario e Scienza Delle Finanze, vol. 67, no. 3, pp. 295-323.

67. Wallis, J.J. and Oates, W.E., 'Decentralization in the Public Sector: An Empirical Study of State and Local Government', in Rosen, H. (ed.), Fiscal Federalism: Quantitative Studies, Chicago: University of Chicago Press, 1988, pp. 5-32.

68. Weingast, B.R., 'Second Generation Fiscal Federalism: The Implications of Fiscal Incentives', 2009, Journal of Urban Economics, vol. 65, no. 3, pp. 279-293.

69. Weingast, B.R., 'The Economic Role of Political Institutions: Market-preserving Federalism and Economic Development', 1995, The fournal of Law, Economics and Organization, vol. 11, no. 1, pp. $1-31$.

70. Weingast, B.R., 'The Performance and Stability of Federalism: An Institutional Perspective', in Menard, C. and Shirley, M. (eds.), Handbook of New Institutional Economics, Berlin: Springer, 2008, pp. 149-172.

71. World Bank, 'Database', [Online] available at https://data.worldbank.org/, accessed on January 14, 2021.

72. Wu, A.M. and Lin, M., 'Determinants of Government Size: Evidence from China', 2012, Public Choice, vol. 151, no. 1-2, pp. 255-270.

73. Zhang, S., 'Fiscal Decentralization, Budgetary Transparency, and Local Government Size in China', 2016, Emerging Markets Finance and Trade, vol. 52, no. 7, pp. 1679-1697. 


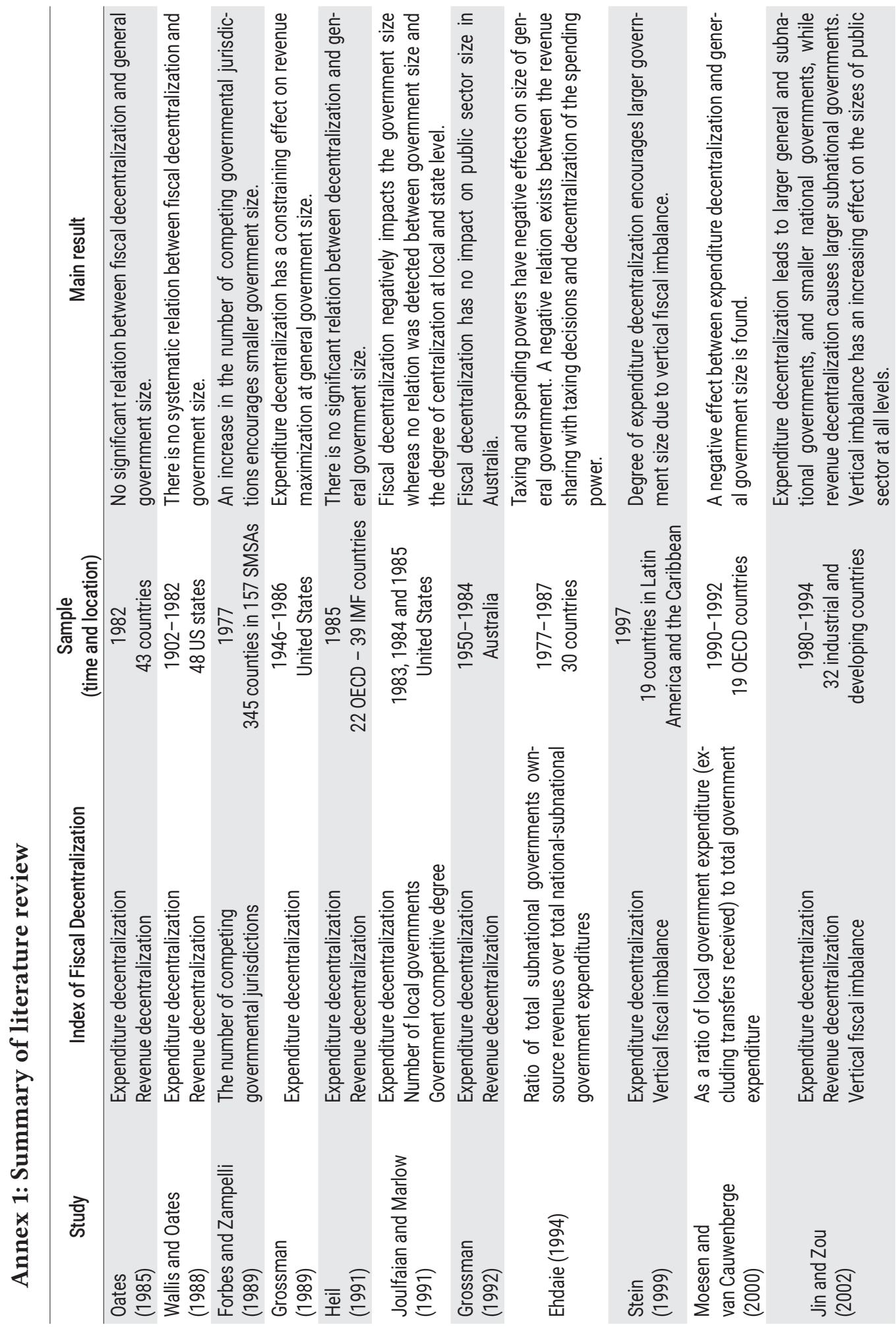




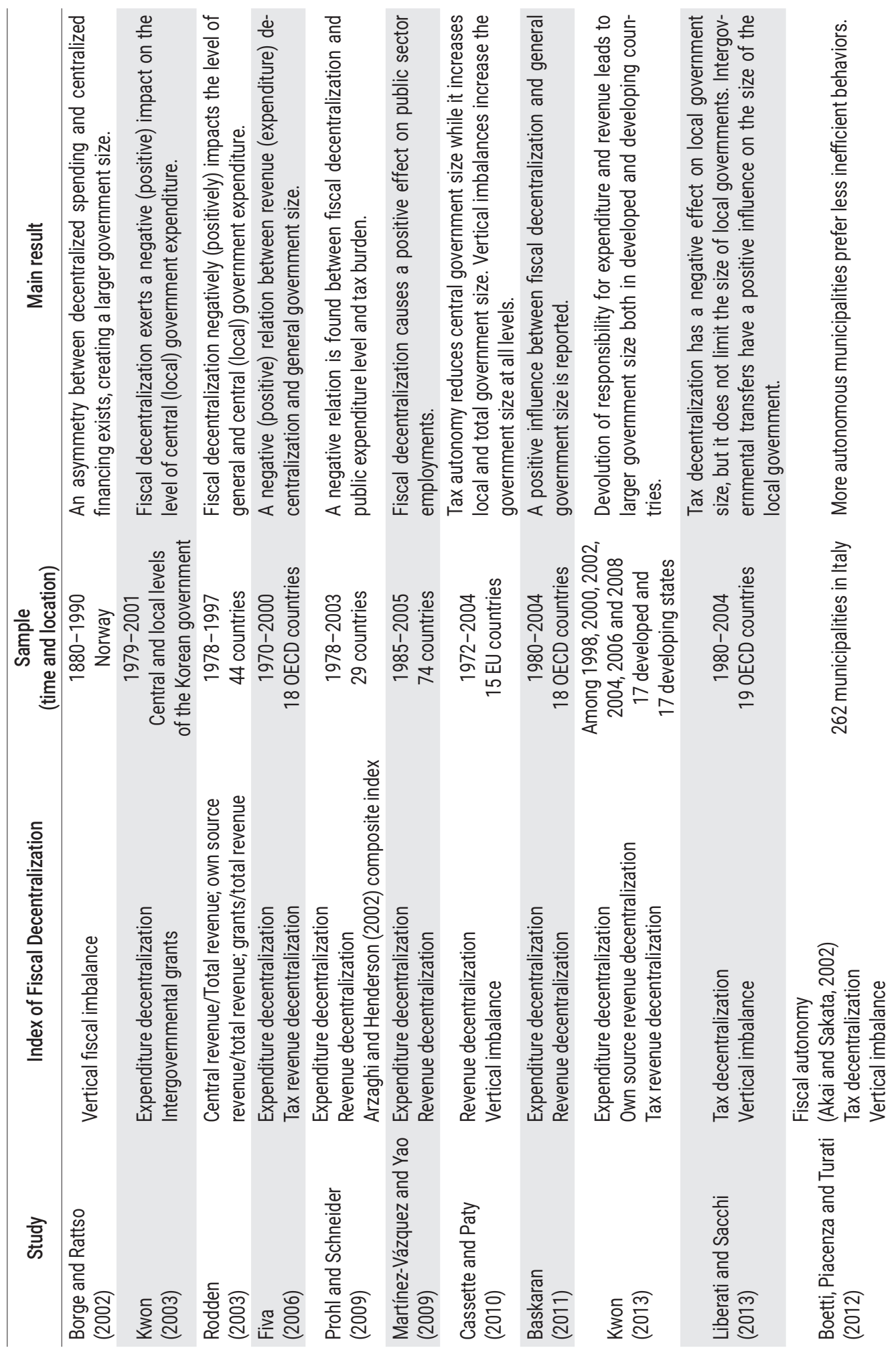




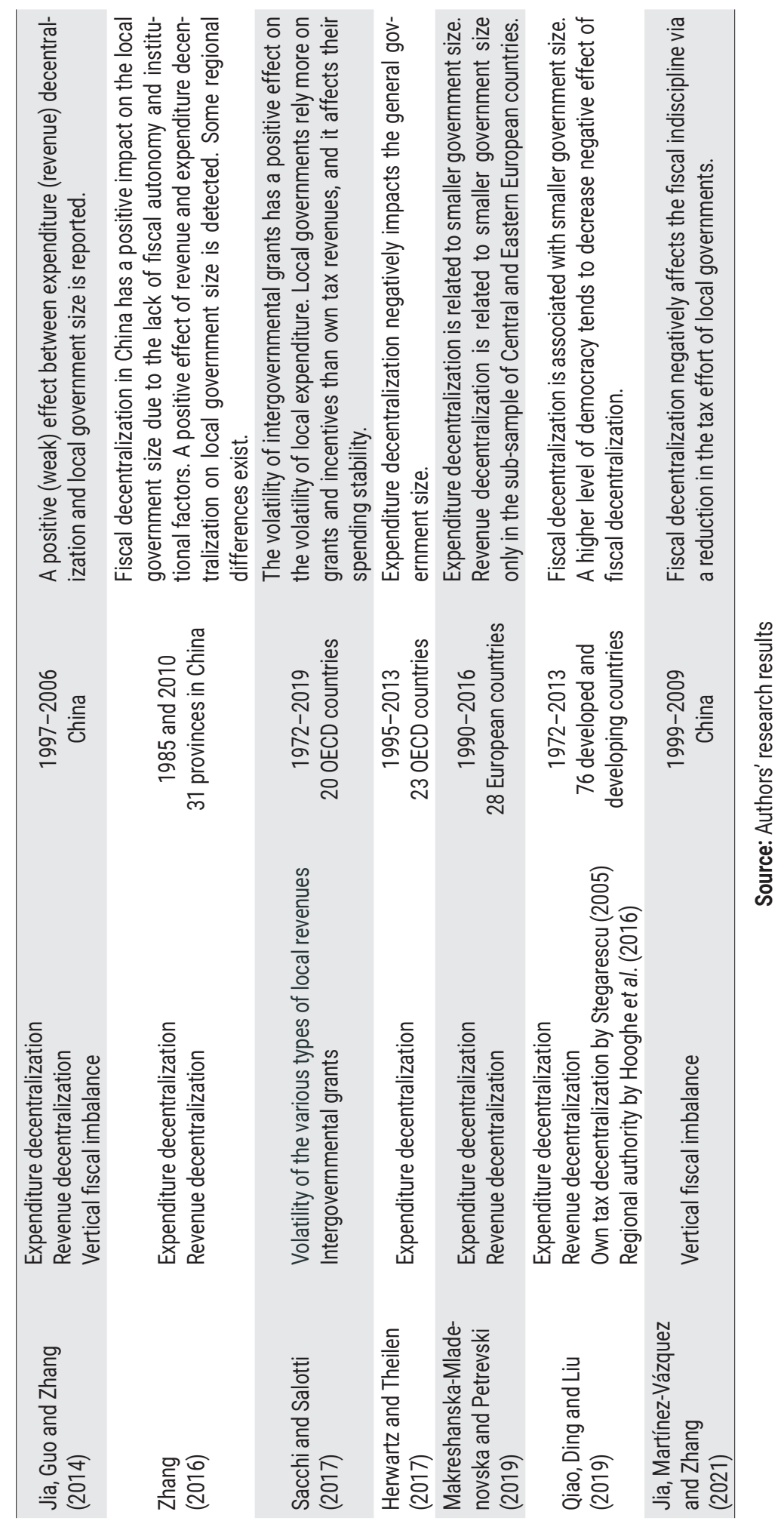

